\title{
Conflict, Mobilization, and Deindustrialization: The 1980 Gardner Strike and Occupation
}

DOI:

10.3828/hsir.2016.37.5

\section{Document Version}

Accepted author manuscript

Link to publication record in Manchester Research Explorer

\section{Citation for published version (APA):}

Mustchin, S. (2016). Conflict, Mobilization, and Deindustrialization: The 1980 Gardner Strike and Occupation. Historical Studies in Industrial Relations, 37, 141-167. https://doi.org/10.3828/hsir.2016.37.5

\section{Published in:}

Historical Studies in Industrial Relations

\section{Citing this paper}

Please note that where the full-text provided on Manchester Research Explorer is the Author Accepted Manuscript or Proof version this may differ from the final Published version. If citing, it is advised that you check and use the publisher's definitive version.

\section{General rights}

Copyright and moral rights for the publications made accessible in the Research Explorer are retained by the authors and/or other copyright owners and it is a condition of accessing publications that users recognise and abide by the legal requirements associated with these rights.

\section{Takedown policy}

If you believe that this document breaches copyright please refer to the University of Manchester's Takedown Procedures [http://man.ac.uk/04Y6Bo] or contact uml.scholarlycommunications@manchester.ac.uk providing relevant details, so we can investigate your claim.

\section{OPEN ACCESS}




\title{
Conflict, Mobilization, and Deindustrialization: The 1980 Gardner Strike and Occupation Stephen Mustchin
}

\author{
Originally published in Historical Studies in Industrial \\ Relations, No.37 (2016)
}

The diesel engine manufacturer, L. Gardner and Sons, was the site of a series of industrial disputes from the late 1960s. Two long strikes in 1968 and late 1972 were the backdrop for a more militant shop -steward leadership emerging. Between them, in early 1972, district union officials had to fight to reverse a company-organized ballot at Gardner, which had accepted a poor settlement during the Greater Manchester-wide engineering pay and hours dispute that saw up to thirty factories occupied by their workforces. Within a year, the Gardner factory was itself the site of a long occupation for higher wages. This was the precursor to the high-profile occupation in 1980 against mass redundancies at the height of the manufacturing recession.

Founded in Hulme, south Manchester in 1868, Gardner moved a few miles to Patricroft in Eccles in 1899. It manufactured engines for regionally based truck and bus manufacturers, and by 1945 produced around 3,000 engines per year for the domestic vehicle and marine market, exporting significant numbers to the British Commonwealth. From 1945 until the late 1970s it employed between 2,000 and 3,000 workers at this single site. ${ }^{1}$ The 1980 strike occurred as the overall number of strikes fell sharply from 2,080 in 1979 to 1,330 in 1980 (and were to decline continuously after 1984). ${ }^{2}$

1 M. Halton, 'L. Gardner and Sons Limited: The History of a British Industrial Firm. A Study with Special Reference to Markets, Workplace Industrial Relations, and Manufacturing Engineering Technology, 1955-1986' (Ph.D., University of Bolton, 2010), pp. 18-29.

2 D. Lyddon, 'From Strike Wave to Strike Drought: The United Kingdom, 1968-2005', in S. van der Velden, H. Dribbusch, D. Lyddon and K. Vandaele (eds), Strikes around the World, 1968-2005: Case-Studies of 15 Countries (Aksant, Amsterdam: 2007), p. 365. 
Within this period of 'labour quiescence', ${ }^{3}$ the 1980 strike represented a rare 'victory' in an otherwise difficult period for the union movement, ${ }^{4}$ 'one of the most determined fightbacks against unemployment since the Conservative Party took office in May 1979, with some trade- unionists suggesting - rather optimistically - that it will be the [Margaret] Thatcher government's Upper Clyde Shipbuilders." ${ }^{5}$ One claim was that it showed 'that there is an alternative of fighting sackings to waiting three or four years for a Labour government' $;{ }^{6}$ and the strikers argued that 'victory for the Gardners workforce would be an inspiration to all workers who detest this Government's policies'?

The 1980 strike prevented a large number of compulsory redundancies and was remarkable for the dynamism demonstrated by those involved: 'in no sense a clear victory against redundancy but it was a partial victory for some measure of shop steward control over the process. ${ }^{8}$ Examples drawing on the strike's organization were highlighted by John McIlroy in his manual on industrial action. ${ }^{9}$ However, the firm's position deteriorated after 1980, with ongoing, mostly voluntary, redundancies, short-time working, victimization of key union activists, and the wider context of recession and falling demand for Gardner engines.

Based on archival material and interviews with participants, ${ }^{10}$ this article explores the struggle between militant and 'moderate' trade-unionism in this engineering firm from the late 1960 s to the early 1980s. It

3 M. Shalev, 'The Resurgence of Labour Quiescence', in M. Regini (ed.), The Future of Labour Movements (Sage: 1992), pp. 102-32.

4 D. Sherry, Occupy! A Short History of Workers' Occupations (Bookmarks: 2010), pp. 131-3.

5 P. Wintour, 'Lovely for Some in the Gardner', New Statesman, 7 November 1980.

6 C. Harman, 'Organising for Occupation', Socialist Review (Soc. Rev.) (November 1980).

7 Collection letter from Gardner Joint Shop Stewards' Committee (JSSC) (1980), 'Fighting Redundancies at Gardners', ORG/GARDNER, Working Class Movement Library, Salford (WCML).

8 S. Aaronovitch, 'Unemployment - Halting the Slide', Marxism Today (May 1981).

9 J. McIlroy, Strike! How to Fight, How to Win (Pluto: 1984).

10 Most archival material is from extensive holdings on L. Gardner and Sons in the WCML, Salford; strike materials held by Geoff Brown, a trade-unionist close to the dispute, including the diary of a senior shop steward, which are to be deposited in the WCML; and materials held by Tommy Macafee, convener during the occupation. Interviews with six participants were held in

2014-15, including two 90-minute interviews and numerous discussions with Carl Lingard, who worked at Gardner (1967-86). I thank Carl and Geoff for comments on an earlier draft, WCML staff, and Tommy and others who were interviewed. 
analyses the economic, political and industrial relations context of the early 1980s, before discussing the phenomenon of workplace occupations. The development of shop-floor organization and industrial relations at Gardner is then outlined, with particular attention to the incidents of industrial action. This is followed by a detailed analysis of the 1980 strike and occupation. The employer countermobilization in its wake saw the factory union leadership change and a more quiescent approach to the continual round of redundancies and eventual factory closure as Gardner's specialist engines were squeezed out of the commercial vehicle market.

\section{Industrial change and industrial relations under the first Thatcher government}

The 1979-83 Conservative government was marked by recession, the onset of legislative restructuring of industrial relations and a sharp fall in the number of strikes, so the 1980 occupation stood out as a significant act of resistance. ${ }^{11}$ It took place at the height of the 1980-81 recession, when strict 'monetarist' policy (focused on controlling inflation through the money supply while tolerating high unemployment and marginalizing unions) $)^{12}$ had raised exchange rates and interest rates. These placed constraints on manufacturing exports and investment, leading to public complaints from employers and the labour movement. Attempts to mobilize the unions in a campaign of opposition to legal changes, recession and rising unemployment culminated in a patchily supported Day of Action organized by the Trades Union Congress (TUC) in May 1980; some strikes took place but its overall failure demonstrated 'the inability of the TUC either to challenge the government or to co-ordinate the actions of its member unions. ${ }^{13}$

Challenges to the unions in the 1980s were incremental: the 1980 Employment Act started the process but even the more draconian 1982 Employment Act (opening unions up to injunctions and damages) was viewed by Prime Minister Thatcher as inadequate. She complained of the persistence of the closed shop, union membership density of nearly $50 \%$ and 'too much socialism in Britain'. ${ }^{14}$ The 1980 Act was deemed relatively moderate with a limited scope, with the minister responsible, James Prior,

11 Sherry, Occupy!, p. 131.

12 P. Davies and M. Freedland, Labour Legislation and Public Policy (Oxford University Press: 1993), pp. 430-4.

13 C. Crouch, The Politics of Industrial Relations (2nd edn; Fontana: 1982), p. 127.

14 H. Beynon, "'Still Too Much Socialism in Britain": The Legacy of Margaret Thatcher', Industrial Relations Journal 45:3 (2014), pp. 214-33, at p. 226. 
pressurized and ultimately replaced. ${ }^{15}$ A Code of Practice, attempting to limit pickets to six, did not come into force until 17 December $1980,{ }^{16}$ so was not functioning at the time of the Gardner occupation, but was to acquire greater force as a result of litigation during the $1984-85$ miners' strike. ${ }^{17}$ Immunities for workers occupying workplaces were subsequently removed in the $1982 \mathrm{Act} ;{ }^{18}$ and the balloting requirements for official strikes imposed by the 1984 Trade Union Act would further limit future actions similar to Gardner's.

Policy- makers commonly blamed industrial relations for economic problems, rather than looking to weaknesses in corporate governance, finance, and training systems; the state was more willing to intervene in industrial relations than these other issues. ${ }^{19}$ Chief executives such as Michael Edwardes at British Leyland (appointed under the previous Labour government), and Ian McGregor in steel and later coal, played a major role in demonstrating to other employers that confronting unions was increasingly feasible given the new economic, and then legal, environment. ${ }^{20}$ Edwardes orchestrated the sacking of Derek Robinson, the convener at the Longbridge plant, in November 1979 after a series of management-organized workforce ballots to secure consent for restructuring that bypassed union structures. ${ }^{21}$ Focusing on the Thatcher period can obscure continuities in the British state's relationship with capital and approach to tradeunionism. ${ }^{22}$ Major defeats such as of the miners in 1984-85, the 'rejection of militancy'

15 P. Dorey, 'Weakening the Trade Unions, One Step at a Time: The Thatcher Governments' Strategy for the Reform of Trade-Union Law, 1979-1984', Historical Studies in Industrial Relations (HSIR) 37 (2016), pp. 169-200.

16 Department of Employment, Code of Practice, Picketing (1980).

17 Davies and Freedland, Labour Legislation, p. 461.

18 P. Findlay, 'Resistance, Restructuring and Gender: The Plessey Occupation', in T. Dickson and D. Judge (eds), The Politics of Industrial Closure (Macmillan: 1987), pp. 70-95, at p. 84.

19 C. Howell, Trade Unions and the State: The Construction of Industrial Relations Institutions in Britain, 1890-2000 (Princeton University Press, Princeton, NJ: 2005), pp. 136-42.

20 J. MacInnes, Thatcherism at Work: Industrial Relations and Economic Change (Open University Press, Milton Keynes: 1987), p. 3.

21 S. Jeffreys, 'The Changing Face of Conflict: Shopfloor Organization at Longbridge, 1939-1980', in M. Terry and P. Edwards (eds), Shopfloor Politics and Job Controls: The Post-war Engineering Industry (Blackwell, Oxford: 1988), pp. 53-83 at p. 81. Between 1977 and 1980 British Leyland management conducted five ballots of the workforce on bargaining reform, incentive schemes, parity payments, restructuring and pay: M. Golden, Heroic Defeats: The Politics of Job Loss (Cambridge University Press: 1997), pp. 47-8.

22 C. Rogers, 'From Union Legislation to Financial Reform: A Reflection on Thatcherism, Capital and the British State', Capital and Class 38:2 (2014), pp. 289-302, at p. 300 . 
that such events were argued to imply, ${ }^{23}$ the 'rediscovery of management prerogative', ${ }^{24}$ and the wider climate of 'coercive pacification', ${ }^{25}$ led to a decrease in strikes, increasingly unitary management approaches, and a wider 'decollectivization' of industrial relations. ${ }^{26}$

Manufacturing employment in the UK fell, from its 1966 peak, continuously during the 1970s and particularly in the early 1980s. This decline has been attributed to the cultural undervaluing of industry in Britain, the dominance of short-term financial interests, and the state's emphasis on investing in the welfare state rather than industrial modernization after the Second World War. ${ }^{27}$ Innovation and investment were skewed towards the 'military-industrial-scientific complex ... while other parts of the British economy and society fell apart'. ${ }^{28}$ This is relevant to Gardner, which was slow to modernize its production processes and product lines in the 1970s and 1980s; it was acquired by Hawker Siddeley with capital gained after the nationalization of its aerospace division in 1977. The nationalization of British Leyland, the aircraft industry, and shipbuilding between 1975 and 1977 had a major impact on British engineering. Their subsequent privatization during the 1980s created further pressures on unions, workers and the constituent workplaces. ${ }^{29}$ The particularities of British capitalism and the role of the state had an impact on Gardner and its subsequent decline.

Such 'declinist' accounts often blame workers, unions and their supposedly negative impact on productivity for the erosion of industry. ${ }^{30}$ Yet underinvestment and management problems were evident at Gardner, which maintained a piecework system because of its relatively small

23 P. Bassett, Strike Free: New Industrial Relations in Britain (Papermac: 1987), p. 12.

24 J. Purcell, 'The Rediscovery of the Management Prerogative: The Management of Labour Relations in the 1980s', Oxford Review of Economic Policy 7:1 (1991), pp. 33-43.

25 R. Hyman, Strikes (4th edn; Macmillan: 1989), p. 199.

26 Howell, Trade Unions and the State, p. 132.

27 M. Kirby, 'Britain's "Manifest Industrial Destiny": The Culture of High Technology and Industrial Performance in the Twentieth Century', Business and Economic History 26:2 (1997), pp.751-68; J. Tomlinson, 'Thrice Denied:

"Declinism" as a Recurrent Theme in British History in the Long Twentieth Century', Twentieth Century British History 20:2 (2009), pp. 227-51.

28 D. Edgerton, 'Liberal Militarism and the British State', New Left Review 185 (1991), pp. 138-69, at p. 165.

29 M. Florio, The Great Divestiture: Evaluating the Welfare Impact of the British Privatizations 1979-1997 (MIT Press, Cambridge, MA: 2006).

30 T. Nichols, The British Worker Question: A New Look at Workers and Productivity in Manufacturing (Routledge and Kegan Paul: 1986); P. Nolan and P. Marginson, 'Skating on Thin Ice? David Metcalf on Trade Unions and Productivity', British Journal of Industrial Relations (BJIR) 28:2 (1990), pp. 227-47. 
volumes of production that fell further in the 1980s. The use of piece rates in engineering had risen in the post-war period, with many firms using them to increase productivity and motivation among manual workers, although the 1968 Donovan Report highlighted that 'in many factories work study is not in use even today and prices are fixed by bargaining methods often described as those of a "Persian market". ${ }^{31}$ In practice, under conditions of 'full' employment, piecework could contribute significantly to the strengthening of shop-floor union organization, with stewards prominent in negotiations over job times and rates. ${ }^{32}$ Pieceworking in those Manchester engineering firms affiliated to the regional Engineering Employers' Federation (EEF) generally followed the Manchester Piecework Agreement, signed in 1919, that allowed operatives to declare 'daywork' for a fixed payment if there was a dispute over rates. ${ }^{33}$ This tactic was used, for example, in the 1972 pay and hours campaign in Greater Manchester. ${ }^{34}$

The labour process at Gardner was markedly different from that in carassembly plants, with less pressure to implement more unitary approaches that prefigured lean production. ${ }^{35}$ The local engineering union district committee was frequently involved in disputes procedures in workplaces where pieceworking remained. ${ }^{36}$ Shop-floor disputes were common and, in 1973 and afterwards, developed into much wider stoppages.

\section{Strikes and the decline of workplace occupations}

Gardner was not especially strike -prone, but long strikes in 1968, 1972 and 1973 established far stronger, more militant union organization than before. The strengthening of workplace organization at Gardner parallels the 1968-74 period when union membership and strike incidence rose in many industrialized countries. Despite the upsurge of industrial action in

31 W. Brown, Piecework Abandoned: The Effect of Wage Incentive Systems on Managerial Authority (Heinemann: 1962), pp. 2-3; Royal Commission on Trade Unions and Employers' Associations, 1965-68 (Donovan), Report, Cmnd 3623 (1968), para. 89.

32 W. Brown, Piecework Bargaining (Heinemann: 1973), ch. 5.

33 Halton, 'L. Gardner and Sons', p. 146.

34 R. Darlington and D. Lyddon, Glorious Summer: Class Struggle in Britain, 1972 (Bookmarks: 2001), p. 110.

35 P. Stewart, M. Richardson, A. Danford, K. Murphy, T. Richardson and V. Wass, We Sell Our Time No More: Workers' Struggles against Lean Production in the British Car Industry (Pluto: 2009), pp. 34-5.

36 I. Boraston, H. Clegg and M. Rimmer, Workplace and Union (Heinemann: 1975), pp. 30-2. 
the 1978-79 'Winter of Discontent', ${ }^{37}$ strike incidence fell during 1979 and markedly in $1980 .^{38}$ The 1980 Gardner strike was deemed to be successful, delaying mass redundancies and maintaining some union influence over staffing levels, but these gains were temporary and eroded by the wider context of recession and increasingly aggressive management. This capacity to resist was founded on nearly twenty years of workplace conflict at Gardner rather than a spontaneous reaction to the economic and political context of the period.

Occupation represented 'a revolutionary tactic, albeit for reformist demands' ${ }^{39}$ A wave of high-profile occupations had taken place in the 1970s, including those at Upper Clyde Shipbuilders (1971-72), Fisher-Bendix on Merseyside (1972), and engineering firms in Greater Manchester and elsewhere in 1972, but they became far less common in the 1980 s. $^{40}$ Occupations in the early 1980s at Gardner, Meccano, Plessey, Lee Jeans, Caterpillar, Cammell Laird and Laurence Scott countered this trend. ${ }^{41}$ But legal changes, employers' increasing use of injunctions and more interventionist policing made occupation harder to organize and sustain. ${ }^{42}$ Many occupations in the 1970 s assertively sought improvements in pay, working conditions, and in some cases experiments with workers' control, but in the 1980s were more typically a defensive last resort against redundancy and factory closures. ${ }^{43}$ The 1980 Gardner occupation had both defensive and assertive features, opposing redundancies while demanding reorganization

37 T. Martin López, The Winter of Discontent: Myth, Memory, and History (Liverpool University Press: 2014); though also see D. Lyddon, 'Striking Facts about the "Winter of Discontent", HSIR 36 (2015), pp. 205-18.

38 J. Godard, 'What Has Happened to Strikes?', BJIR 49:2 (2011), pp. 282-305.

39 Socialist Worker, 22 November 1980.

40 A. Tuckman, 'Workers' Control and the Politics of Factory Occupation', in I. Ness and D. Azzelini (eds), Ours to Master and to Own: Workers' Control from the Commune to the Present (Haymarket, Chicago, IL: 2011), pp. 284301; Darlington and Lyddon, Glorious Summer, pp. 95-134.

$41 \mathrm{~K}$. Brown, 'Unions and Management in Engineering: A Case Study, 196479', Business History 47:1 (2006), pp. 86-101; Findlay, 'Resistance, Restructuring and Gender'; N. Lorentzen, “'You can't fight for jobs and just sit there": The Lee Jeans Sit-in', in H. Levie, D. Gregory and N. Lorentzen (eds), Fighting Closures: De-Industrialization and the Trade Unions 19791983 (Spokesman, Nottingham: 1984), pp. 43-62; C. Woolfson and J. Foster, Track Record: The Story of the Caterpillar Occupation (Verso: 1988); S. Mustchin, 'From

Workplace Occupation to Mass Imprisonment: The 1984 Strike at Cammell Laird Shipbuilders', HSIR 31/32 (2011), pp. 31-61; C. Love, Conflicts over Closure: The Laurence Scott Affair (Avebury, Aldershot: 1988).

42 S. Evans, 'The Use of Injunctions in Industrial Disputes', BJIR 23:1 (1985), pp. 133-7.

43 J. Greenwood, Worker Sit-Ins and Job Protection (Gower, Farnborough: 1977), p. 84; Tuckman, 'Workers' Control'. 
and work-sharing to survive the economic recession, framed in broader terms addressing regional unemployment, solidarity, and shared sacrifice. The wider significance of occupations can be overstated but the resolve, determination, and organization of the participants deserve to be documented and analysed.

The events in the Gardner dispute broadly correspond to the framework set out within mobilization theory: perceived injustices led to the development of stronger union organization, with strikes playing a key role in mobilizing the workforce. Grievances about the confrontational management regime at Gardner stimulated recruitment to the union, stronger workplace organi-zation, the establishment of a closed shop and strengthened influence over job times and work organization. ${ }^{44}$ Militant workplace trade -unionism and key activists were instrumental in directing these grievances into collective organization, with a leadership maintaining autonomy from, and a critical relationship with, the national union. Such approaches allowed for gains from the union side but have often led to repercussions. ${ }^{45}$

Counter-mobilization by employers and the state is highlighted by John Kelly but often underemphasized in accounts using this framework; these dynamics in the Gardner dispute are analysed below. ${ }^{46}$ The role of shop stewards, their differing orientations and their integration within social networks, unions, and strike organization are also examined. ${ }^{47}$ The specific nature of strikes is also important: while the 1968 and 1972 strikes at Gardner started over victimization and the 1973 occupation was over pay, the 1980 strike was a reaction to compulsory redundancies. One analysis of strikes over job losses argues that they 'are not whatever their slogans may suggest - aimed at preventing job loss. Rather, they seek to defend the trade union organization during the course of downsizing. ${ }^{48}$, This is questionable. Analysis of other strikes against job loss in the early 1980s highlights attempts to secure improved redundancy payments, to protect jobs, and to devise alternative means of maintaining threatened industries. ${ }^{49}$ While defending union organization was crucial, Miriam Golden's emphasis on this is partial and minimizes workers' sacrifices in such situations in order to address wider, less institutional aims. The Gardner case shows how, as

44 J. Kelly, Rethinking Industrial Relations: Mobilization, Collectivism and Long Waves (Routledge: 1998).

45 P. Smith, Unionization and Union Leadership: The Road Haulage Industry (Continuum: 2001), pp. 23, 13.

46 Ibid.

47 E. Batstone, I. Boraston and S. Frenkel, The Social Organization of Strikes (Blackwell, Oxford: 1978).

48 Golden, Heroic Defeats, p. 4.

49 H. Levie, D. Gregory and N. Lorentzen, 'Overview', in Levie et al., Fighting Closures, pp. 9-17. 
in mobilization theory, conflict fostered strong workplace organization and capacity to strike but was followed by management counter-mobilization, highlighting the difficulty of sustaining gains.

\section{Strikes and workplace organization within Gardner}

Prior to the late 1960s, Gardner management viewed itself as taking a 'paternalist' approach to the workforce: ${ }^{.0}$ 'the employer's expectations of obedience and hierarchical order ... with a reciprocal promise and duty of social responsibility for the worker's well-being. ${ }^{51}$ Shop stewards were relatively moderate and a significant non- union component of the workforce had developed after the 'dilution' of skilled grades from the late 1950s. Gardner workers had supported the 1926 General Strike, restored motorcycles to be donated to Voluntary Aid to Spain during the (1936-39) Spanish Civil War, and engaged with campaigns such as the 1947 Manchester-wide apprentices' strike, but union membership had declined after 1926 and organization was weak until the early 1970 s. $^{52}$

The engineering union in this period was divided, with its right wing typically the source of its leaders and a majority on the full-time executive council and the policy-making lay national committee. Hugh Scanlon's term as president from 1968 to 1979 saw the broad left in the union strengthened, but, from 1980, under the leadership of Terry Duffy and John Boyd, the union's left was increasingly marginalized at national level. But the Manchester district was still heavily influenced by the broad left. ${ }^{53}$ The divisional organizer, John Tocher, a relatively prominent Communist Party (CP) member, was a key figure who came to prominence during the 1966-68 Roberts-Arundel strike in Stockport and the wave of workplace occupations in Greater Manchester in 1972. ${ }^{54}$

In the 1960s, wages at Gardner were lower than at comparable employers; fewer than half of the 2,000 shop-floor workers were union members, mostly skilled engineering workers in the Amalgamated Engineering Union, with lessskilled workers generally unorganized.

50 Halton, 'L. Gardner and Sons', pp. 92-3.

51 P. Ackers, 'On Paternalism: Seven Observations on the Uses and Abuses of the Concept in Industrial Relations, Past and Present', HSIR 5 (1998), pp. 173-93.

52 E. Frow, Engineering Struggles: Episodes in the Story of the Shop Stewards' Movement (Working Class Movement Library, Manchester: 1982), p. 107; Halton, 'L. Gardner and Sons', p. 92.

53 L. James, Power in a Trade Union: The Role of the District Committee in the AUEW (Cambridge University Press: 1984).

54 J. Arnison, The Million Pound Strike (Lawrence and Wishart: 1971); Darlington and Lyddon, Glorious Summer, pp. 95-134. 
An account based on interviews with stewards described how 'most supervision were vicious and reducing workers to tears was not uncommon... A director once sacked a man on Christmas Eve for having his coat on early ... Typically the steward would just stand there and watch you take a bollocking. ${ }^{, 55}$ A former steward who joined the firm in 1967 described union organization as 'pitiful', the workforce 'downtrodden', with very old machine tools used with belt- driven lathes: 'they looked scared ... [W]orkers had no stomach for any change ... [I]t's not just the equipment that's outdated but the feel of it. ${ }^{, 56}$ The personnel manager in place during the 1980 strike allegedly boasted that he had once sacked his own nephew. ${ }^{57}$ Senior engineers who were closer to management indicated that this reputation was 'probably fair', although they felt that these conditions were exaggerated by the union side. ${ }^{58}$

The relationship between management and workforce deteriorated during the 1960s. Under the leadership of T. F. Farrell, the works convener between 1963 and 1966, stricter limits were placed on overtime, apprentice training, and health and safety. Overtime bans and the use of the Manchester Piecework Agreement for the first time at Gardner in the post-war period forced an increasingly controlling, authoritarian management to negotiate over wages, but the firm reacted by moving Farrell to a different department for the ostensible purposes of 'production efficiency', after which he resigned as convener. ${ }^{59}$ This context of assertive union organization, management reprisals and the enduring role of more moderate or quiescent shop stewards formed the backdrop for the series of disputes that developed from the late 1960s onwards.

The ten-week foundry strike, starting at the end of August 1968, was described as caused by disciplinary action over 'faulty workmanship' in an account based on shop stewards' committee minutes; ${ }^{60}$ but an account using management recollections claimed a moulder in the foundry 'for some reason only known to him' had been casting the Gardner logo upside down on crankcases. ${ }^{61} \mathrm{He}$ was dismissed; 250 workers struck in solidarity and were dismissed themselves; many workers crossed picket lines during this dispute. The Amalgamated Union of Engineering and

55 'Workers' Organisation at Gardners: Its Rise and Fall, 1972-1982' (unpublished, n.d.), Geoff Brown collection (henceforth 'GB WCML').

56 Interview, former Gardner shop steward, February 2015.

57 'Workers' Organisation at Gardners', GB WCML.

58 Interview, former Gardner senior engineer, May 2015; interview, former Gardner apprentice engineer, April 2015.

59 Halton, 'L. Gardner and Sons', p. 95.

60 Ibid., pp. 97-9.

61 G. Edge, L. Gardner \& Sons Limited: Legendary Engineering Excellence, Transport Archive Series (Gingerford Publications, Cambridge: 2002), p. 180. 
Foundry Workers made the strike official after two weeks, and strikers returned in November with no break in service. Six hundred skilled employees left after this strike, but the dispute provided the basis for the more assertive union organization established over the next decade. After 1968, management believed that the firm was 'targeted' by left-wing union activists due to its relatively weak level of organization and the works director's position as regional head of the EEF (namely the South Lancashire, Cheshire and North Wales Engineering Employers' Association), a role that put further constraints on potential pay awards given the various statutory incomes policies. ${ }^{62}$

During the 1972 engineering sit-ins in Greater Manchester over the national pay and hours claim, the Gardner workforce, which did not take part, voted to accept a deal involving a pay rise only half of that called for at the start of the regional dispute, with no concessions on hours or holidays. The Confederation of Shipbuilding and Engineering Unions (CSEU) district committee refused to ratify the deal, arguing that it undermined the wider campaign. When Tocher announced he would address the workers, the firm threatened to invoke the 1971 Industrial Relations Act against him for inducing a breach of contract. ${ }^{63}$ The meeting went ahead at a local bingo hall and reversed the earlier vote, despite workers having received the pay increase for the previous two weeks. Tocher argued that foremen had given out ballot papers: 'We did not consider the ballot was free from intimidation and therefore believed it was not binding on the members concerned'. ${ }^{64}$

When, in September of the same year, a shop steward was ordered to move off his machine to be replaced by an apprentice, his refusal led to his dismissal and a strike by sixty-eight machine-shop workers. After five weeks, a meeting of laid-off workers agreed that supervisors could do the work of strikers. The Amalgamated Union of Engineering Workers (AUEW) district secretary then bypassed the convener, who was viewed as ineffective and too close to management, and called a mass meeting of AUEW members who agreed to join the strike. A district levy, to support the strikers, was proposed and threats made to block any Gardner products. Management capitulated after a few days, in early November, reinstating the dismissed steward and agreeing not to replace skilled workers with apprentices in future. More assertive union representatives were elected. Thus the 1968 and 1972 strikes were critical in establishing a stronger union presence within the firm. ${ }^{65}$

62 Ibid., p. 179; interview, former Gardner senior engineer, May 2015.

63 Darlington and Lyddon, Glorious Summer, pp. 121-2; The Times, 22 April 1972.

64 Guardian, 22 April 1972.

65 Halton, 'L. Gardner and Sons', pp. 100-1. 
This influenced the major strike and occupation that occurred in 1973. In an attempt to circumvent the pay policy of the Conservative government, ${ }^{66}$ the workers demanded an increase in their production bonus. A work-to-rule followed, with day-work declared under the Manchester Piecework Agreement. Gardner and the EEF withdrew from negotiations, escalating the dispute and threatening participants in the work- to -rule and anyone else supporting the strike with dismissal (effectively a lockout), leading to a plant-wide strike and the occupation of some sections of the factory. ${ }^{67}$

A number of manual unions made the strike official, but not the staff unions, unlike their role in the 1980 strike. ${ }^{68}$ Some workers who broke the strike were reportedly attacked, in the loading bay, by occupiers with missiles, including bags of urine. ${ }^{69}$ Engineering workers from across the city attended the pickets which were crossed by non-strikers under police protection; the strike was ultimately settled after fourteen weeks in June $1973 .{ }^{70}$ Some stewards had broken the workto-rule and undermined the strike leading to the withdrawal of their credentials by their unions, part of a broader process of more quiescent union leaders being sidelined in the period to be replaced by more militant, assertive activists. The strike had also led many supervisors who had worked during the strike to join staff unions, such as the Association of Scientific, Technical and Managerial Staffs (ASTMS). ${ }^{71}$ The strike did not fully achieve its aims but was significant in building stronger workplace organization, with an effective closed shop established after its end. $^{72}$ The 1973 strike was an aggressive occupation to improve pay and conditions, in contrast to the more defensive occupation of 1980. Union organization was strengthened, and an increasingly politicized leadership was able to sustain the factory occupation in 1980.

The Gardner family were 'disenchanted' and 'hurt' by the lack of loyalty they felt the workers had demonstrated. The owners had not expanded the company due to fears of losing control if they borrowed and brought in external directors, but also to maintain steady levels of employment, avoid forced layoffs during recessions, and to keep the workforce ostensibly more content. This lack of expansion meant that waiting lists for Gardner engines often exceeded twelve months during peak demand in the mid-1970s; the 1973 strike exacerbated these delays, and a number of truck manufacturers

66 Darlington and Lyddon, Glorious Summer, pp. 11-12.

67 Ibid., pp. 102-5.

68 Guardian, 7 April 1973.

69 Interview former Gardner senior engineer, May 2015; 'Workers' Organisation at Gardners', GB WCML.

70 Halton, 'L. Gardner and Sons', pp. 102-5; Guardian, 16 June 1973.

71 'Workers' Organisation at Gardners', GB WCML.

72 Edge, L. Gardner \& Sons Limited, p. 179. 
switched permanently to other suppliers during the dispute. ${ }^{73}$ Gardner engines were typically more expensive than alternatives due to the use of higher-quality materials and the complexity of their manufacture, but were more efficient and durable than the competition; within a year of use a Gardner engine would typically save the difference in initial cost on fuel. ${ }^{74}$ However, competitors such as Scania, Volvo, Mercedes, and DAF capitalized on Gardner's lengthening delivery times and strike disruption. ${ }^{75}$

After 1973, a pre-entry closed shop was established for skilled trades, with unskilled and semi- skilled workers expected to join a union when beginning employment. ${ }^{76}$ The joint shop stewards' committee (JSSC) expanded to seventyone members at its peak, drawn from ten unions affiliated to the CSEU, including the majority AUEW, General and Municipal Workers' Union, Transport and General Workers' Union, AUEW Technical, Administrative and Supervisory Section (TASS), ASTMS, and the Association of Professional, Executive, Clerical and Computer Staff (APEX), with four health and safety representatives seconded almost full time. ${ }^{77}$ The AUEW-dominated works committee of seven elected stewards, including the convener and chairman, provided leadership in the factory. For much of the post-1973 period, Ray Robinson was convener and Tommy Williamson chairman; these two were central in establishing strong organization at Gardner. In late 1979, Tommy Macafee, a toolroom engineer and CP member, was elected convener, with Mick Brightman, a Socialist Workers Party (SWP) activist and steward from the milling section elected to the works committee. ${ }^{78}$ Much was made by the local press of these political affiliations: shop stewards openly supported the Anti-Nazi League and the Right to Work campaign, but only three or four SWP members worked at Gardner and other stewards were mostly Labour supporters, along with a handful of Conservative voters: 'this thing of reds under the bed was a load of nonsense. The upsurge of the union came because of the way the firm treated people, not just at Gardner's but everywhere else ... This nonsense about us all wanting to be out on the cobbles, it's fantasy, people wanted to be working, and see right by their families. ${ }^{79}$

73 Interview, former Gardner senior engineer, May 2015.

74 D. Rhys, 'Heavy Commercial Vehicles: The Survival of the Small Firm', Journal of Industrial Economics 20:3 (1972), pp. 230-52.

75 Edge, L. Gardner \& Sons Limited, p. 176.

76 Interview with former Gardner convener, deputy convener and chairman, 29 January 1981, GB WCML.

77 Interview, former Gardner shop steward, April 2015.

78 'Workers' Organisation at Gardners', GB WCML; Former senior steward, 'L. Gardner and Sons 1980-82' (unpublished diary, February 1983), GB WCML.

79 Interview, former Gardner shop steward, April 2015. 
There were relatively few disputes between 1973 and 1980; orders and demand for labour remained high, pay incrementally improved and a less confrontational approach to industrial relations was adopted by management. Piecework remained a constant source of conflict but this was common in comparable workplaces in the period. Behavioural scientists were brought in to work with employees in the late 1970s, with exercises emphasizing participation and co-operation but viewed sceptically by many: "if the stewards were in a "co-operative" frame of mind ... [rationalization plans] would be so much easier'; 80 'at one point they had us all on the floor playing with models, to get us in the right frame of mind but you could see through this, that was never going to bloody work. ${ }^{, 81}$ Gardner workers took part in the one- and two-day strikes, from August to October 1979, for the national engineering claim of significant rises in national minimum rates, reduced hours, and increased holiday entitlements. ${ }^{82}$ The dispute, involving two million workers at its peak, resulted in a four-year agreement which included the symbolic reduction in the forty- hour working week (which had eluded the unions in the 1972 strikes and occupations) to thirty-nine hours from November 1981. This was viewed as a defeat for the employers and created major tensions within the EEF over national bargaining, which collapsed in $1989 .^{83}$

The major change between the 1973 and 1980 strikes at Gardner was the takeover by Hawker Siddeley, whose famous aerospace division was nationalized in 1977 , followed by the acquisition of Gardner for $£ 14.7$ million in July of that year. ${ }^{84}$ Twelve members of the Gardner family shared $£ 5$ million from the sale. The reliance on a very small design team centred around Hugh Gardner, a lack of marketing strategy or diversification plans, and some complacency regarding future demand for Gardner engines reflected wider tendencies towards short- termism (including a lack of strategic planning and long- term financial investment) that were a feature of many established British firms in the period. ${ }^{85}$ Management became increasingly confrontational, coercive and less willing to engage with unions, and was itself under increasing pressure within the new corporate structure. Hawker Siddeley was a notable anti-union employer: in 1979, it made donations

80 'Workers' Organisation at Gardners', GB WCML.

81 Interview, former Gardner shop steward, February 2015.

82 'Workers' Organisation at Gardners', GB WCML; Former senior steward, 'L. Gardner and Sons 1980-82', GB WCML.

83 S. Joyce, 'The Engineering Employers' Federation and the Crisis of 1989: A Case Study in the Decline of Multi-Employer Bargaining', HSIR 34 (2013), pp. 141-71.

84 Halton, 'L. Gardner and Sons', p. 109; Edge, L. Gardner \& Sons Limited, p. 183.

85 Wintour, 'Lovely for Some in the Gardner', New Statesman. 
to the Conservative-affiliated Centre for Policy Studies and right-wing lobby groups and blacklisting organizations such as the Economic League, Common Cause, and Aims for Freedom and Enterprise. ${ }^{86}$ A shop steward later discovered, through the journalist Paul Foot, that he, and others involved in the strike, were on the Economic League blacklist subscribed to by the EEF. ${ }^{87}$ Hawker Siddeley initially pledged to avoid redundancies, but falling demand and a reactive, unilateral and short-term focused approach to restructuring ultimately provoked the 1980 strike. $^{88}$

\section{The 1980 occupation and its aftermath}

High levels of redundancies, factory closures, stricter disciplinary procedures, and increasing victimization of stewards were evident across British engineering during 1980. In mid-June, the Gardner workforce was put on a four-day week, with the firm applying for the state-funded Short-Time Working Subsidy; ${ }^{89}$ over the summer some sections were working as little as one day per week. ${ }^{90}$ Short-time working meant that management could demand that employees were available to work whenever required; workers could be visited at home by supervisors on layoff days and 'hauled' into work under the threat of losing the subsidy. These conditions increased tensions between management and the workforce and its unions, although a 'bizarre phenomenon' was noted where some younger workers preferred this arrangement as it gave them more leisure time. ${ }^{91}$ In August, the unions presented a complex claim for the lifting of a bonus-rate freeze and a $20 \%$ increase, roughly in line with inflation at the time. Orders were low and while there were hopes that they would recover, the claim was met with a 5\% offer, changes to the piecework system and 700 compulsory redundancies. Some 110 workers then left the firm under a voluntary redundancy arrangement, reducing the figure to 590 (520 manual workers and 70 staff), with 14 shop stewards and the convener on the list. ${ }^{92}$

86 Socialist Worker, 18 October 1980.

87 Interview, former Gardner shop steward, April 2015.

88 Edge, L. Gardner \& Sons Limited, p. 185.

89 Between 1975 and 1984 the Department of Employment administered the Temporary Employment Scheme (from 1979 the Temporary Short-Time

Working Compensation Scheme), which provided subsidies for short-time working to limit or avoid redundancies: S. Deakin and F. Wilkinson, 'The Management of Redundancies in Europe: The Case of Great Britain', Labour 13:1 (1999), pp. 41-89.

90 J. Bamford, 'The Gardners Dispute (1980)' (Certificate in Industrial Relations and Trade Union Studies, n.l.), ORG/GARDNER, WCML.

91 Former senior steward, 'L. Gardner and Sons 1980-82', GB WCML.

92 Ibid.; Bamford, 'The Gardners Dispute (1980)', p. 3, ORG/GARDNER, WCML. 
On 5 September a mass meeting of 2,000 workers was addressed by Tocher and agreed (with only six against) that 'the workforce of L. Gardner and Sons will resist redundancy by taking industrial action if necessary, and call on the board of directors to withdraw their proposals in favour of a work-sharing agreement'. ${ }^{93}$ Union officials reiterated to management that they were open to negotiations on voluntary redundancy and early retirement. The compulsory redundancies were described as 'brutal' but the personnel director, Geoff Howarth, dismissed this characterization as 'bullshit'. ${ }^{94}$ The demand for work- sharing, described as 'a sharing of the misery of the membership" ${ }^{95}$ and 'the right to share hardship', was felt by the personnel director to be potentially viable for a finite period but ultimately impractical due to the uncertain economic context. ${ }^{96}$

The disputes procedure was started in September with meetings held under the auspices of the EEF-CSEU on 12 and 23 September, but without agreement. A mass meeting on 2 October endorsed the 5 September resolution and therefore to strike. The next day, a meeting of stewards and reps voted to occupy the plant 'in the tradition of the factory after the 1973 sit-in'. By $12.30 \mathrm{pm}$, the plant was shut down, management vacated the premises, and by $4.30 \mathrm{pm}$ the entrances were sealed with a picket and lodge established at the gate. Management then used local media to indicate that discussions would not reopen until the occupation ceased, questioning the legitimacy of the strike vote. ${ }^{97}$ On 6 October the convener led a delegation to AUEW headquarters in London: to ensure that the union honoured pledges by Gavin Laird, AUEW executive councillor, at the CSEU conference in September, to support members taking industrial action to save jobs; and to make the dispute official, thus releasing strike pay. ${ }^{98}$ Typically, the union took between six and eight weeks to deem a strike official. Within two weeks, three delegations from Gardner had lobbied the union's leadership; the third threatened that if the strike was not made official that day 'there would be two sit-ins - one in Eccles and the other in the union headquarters'. ${ }^{99}$ All other unions involved swiftly gave official backing to the dispute. ${ }^{100}$ Union strike pay did not arrive until much later, so workers

93 Former senior steward, 'L. Gardner and Sons 1980-82', GB WCML.

94 Report, 'Meeting held between management and union officials on Friday 5th September 1980', ORG/GARDNER, WCML.

95 Amalgamated Union of Engineering Workers (AUEW) Manchester North District, committee, 28 October 1980, TU/ENG, WCML.

96 Daily Mirror, 20 October 1980.

97 Morning Star, 23 September 1980.

98 Ibid., 7 October 1980.

99 Harman, 'Organising for Occupation', Soc. Rev.

100 Document, 17 October 1980, 'Gardners Sit-In' - information sheet, ORG/ GARDNER, WCML; Association of Professional, Executive, Clerical and 
faced major problems. Single workers were not entitled to benefit and faced serious hardships, and under reforms to social security, the Department of Health and Social Security assumed that strike pay was issued from the outset of the strike, deducting this from benefit payments, leaving those on strike and their families on minimal incomes. ${ }^{101}$

Morning pickets typically featured around 200 workers; around 500 would be sitting in at any one time, with around 200 'hard core' and 100 'very hard core' strikers at the centre of the occupation. Around 200 employees did not strike, including senior management, supervision, and some white-collar staff. Most TASS, APEX and ASTMS members respected the dispute, with a considerable number of activists drawn from these unions, but some were fined by their respective unions for ignoring their union's support for the occupation. ${ }^{102}$ A letter appealing to non-strikers acknowledged the hardship, management intimidation, and press depictions of a 'terrifying' image of workers on strike, highlighting the 'organised, civilised and disciplined way' that the strike had been conducted and the callous approach of Hawker Siddeley to redundancy. ${ }^{103}$ A strike committee was established, separate from formal union structures and open to all members not just stewards, allowing large numbers of women and younger male workers to participate fully in the occupation. The convener thought that 'it was amazing; the problem with that of course is that they got themselves really wound up for a fight ... [T] hey had all this energy that they wanted to channel somewhere else, it was giving me nightmares about the return to work and the scabs that were coming back inside. ${ }^{104}$ Sub -committees dealing with picketing, administration, food, entertainment, publicity, safety, and delegations all allowed co-option of strikers to increase participation. ${ }^{105}$

Computer Staff (APEX), general purposes committee, 22 October 1980, TU/ CLERKA/2/A/55, WCML.

101 Morning Star, 10 October 1980. Legislation deducting $£ 12$ from any supplementary benefit entitlement for dependants of strikers, on the assumption that $£ 12$ strike pay was paid, was introduced in the Social Security (no. 2) Act 1980, s. 6. This applied from 24 November 1980 (about when the Gardner strike ended) but, according to the Department of Health and Social Security, it was already 'common practice for strike pay to be taken into account by the Supplementary Benefits Commission when it assessed benefits for strikers' families': Guardian, 20 February 1980.

102 Harman, 'Organising for Occupation', Soc. Rev.; Bamford, 'The Gardners Dispute (1980)', p. 20, ORG/GARDNER, WCML.

103 Letter, n.d., from strike committee, 'Still time to think again', ORG/ GARDNER, WCML.

104 Interview with former Gardner convener, deputy convener and chairman, 29 January 1981, GB WCML.

105 Harman, 'Organising for Occupation', Soc. Rev. 
Film showings were held and arts groups put on performances in the canteen. ${ }^{106} \mathrm{~A}$ six-point code of practice for the occupation was drawn up, demanding that all visitors must be recorded and accompanied by a steward or Gardner employee; 'correct and proper' conduct; safety precautions and cleanliness; no damage; no stealing; and no alcohol. ${ }^{107}$ Rumours circulated that the police would attempt to evict the occupiers; legal advice from AUEW solicitors advised that, provided 'factory discipline' was maintained and that there was no violence or criminal activity, then the firm would need an injunction, which was never pursued. The wider significance of the strike was increasingly apparent as it progressed; Foot, the socialist journalist, visited and wrote supportive articles; this coverage and wider solidarity boosted the confidence of the workers and increasingly framed the dispute as a protest against government policy, job loss and deindustrialization. ${ }^{108}$

Management pressed ahead with plans to force a return to work. A postal ballot was organized, with a letter to all employees stating that two more weeks of lost production would cause permanent damage to the firm and necessitate further job losses. The ballot was a 'yes or no' response to the question 'Do you agree that a secret ballot should be arranged about a return to work?' 109 The regional EEF disapproved and told Gardner management that there would have to be a negotiated settlement, while unions accused Hawker Siddeley of attempting to 'trample on all recognised negotiating procedures by going over the heads of the union and shop stewards'. ${ }^{110}$ It was feared that the ballot could be used as a means to delegitimize the strike as a precursor to a legal injunction and eviction. ${ }^{111}$

The pessimistic projections from management were countered by the strikers, who discovered the factory addressograph, which had the addresses of all employees and within a few hours could print up to 2,000 addressed envelopes. ${ }^{112}$ Contact was made with union conveners from firms that bought Gardner engines, all of whom wrote back confirming that demand for engines remained high. A report on these responses was mailed directly to employees, also noting that Gardner had recently received a

106 Bamford, 'The Gardners Dispute (1980)', pp. 1-5, ORG/GARDNER, WCML.

107 Letter, n.d., JSSC, signed by T. Williamson, Confederation of Shipbuilding and Engineering Unions (CSEU) chairman, "CSEU Notice: "Code of Practice", ORG/GARDNER, WCML.

108 Socialist Worker, 8 November 1980.

109 Letter, 24 October 1980, 'To all employees', signed by G. Howarth, Gardner Personnel Director, ORG/GARDNER, WCML.

110 Morning Star, 7 November 1980.

111 AUEW Manchester North District committee, 28 October 1980, TU/ ENG, WCML.

112 Former senior steward, 'L. Gardner and Sons 1980-82', GB WCML. 
large order for 400 bus engines from South Africa. ${ }^{113}$ Also highlighted were Hawker Siddeley's $32.7 \%$ increase in spending on directors' emoluments and the $24.4 \%$ pay rise to the highest paid director, and its profits of $£ 118$ million, $£ 108$ million and (an estimated) $£ 120$ million for 1978,1979 and 1980 respectively. The Mechanical Engineering Division, which included Gardner, made profits of $£ 41$. 6 million, £53.2 million and $£ 37.1$ million in 1977,1978 and 1979. ${ }^{114}$ Gardner made a trading profit of $£ 435,000$ between April and the end of 1980, but this became a net loss of $£ 90,000$ by April 1981 after the interest rate rises on a loan of $£ 6.8$ million from Hawker Siddeley to invest in new machinery. Increasing amounts of work were being carried out by outside contractors, which employed around 180 , generally non-union, workers. ${ }^{115}$

Further letters included counterarguments linking management strategy to wider developments. One compared Hawker Siddeley's 'campaign of intimidation', through direct communications with the workforce that circumvented union structures, to that of Edwardes at British Leyland, portraying the parent company as a hostile external entity: 'The real ugly face of the Multi National is at last revealed and we must not run away like children from a Halloween mask. ${ }^{116}$ The AUEW and the strike committee refused to recognize the management ballot; 900 workers did not return their papers, a number of which were symbolically burned in front of local journalists on the brazier at the factory gates. ${ }^{117}$ The company claimed that $93 \%$ of respondents backed a secret ballot on a return to work, and attempted to enlist the Bishop of Middleton and another 'industrial person in the district' to oversee the count. The former refused as 'the initiative came from the company only, which was not very helpful', and the latter 'sat through half of the count but then did not continue on the grounds that the unions had not been consulted'. ${ }^{118}$

Influencing opinion among the workforce and the public was very important; the propaganda and publicity committee issued two newsletters per week at the peak of the strike, and around 150,000 leaflets, collection

113 Letter, from JSSC, 14 November 1980, 'All strikers - L. Gardner and Sons CSEU official dispute', ORG/GARDNER, WCML.

114 L. Gardner and Sons Limited, Report of the directors for the year ended 31 December 1980; JSSC, Convenor's Report, n.d., signed T. Macafee: ORG/ GARDNER, WCML.

115 Information sheet, November 1981, 'Did you know that', ORG/ GARDNER, WCML.

116 Newsletter, n.d., signed T. Macafee to all CSEU unions; Convenor's Report, signed T. Macafee, 24 October 1980: ORG/GARDNER, WCML.

117 Morning Star, 31 October 1980; Former senior steward, 'L. Gardner and Sons 1980-82', GB WCML.

118 Letter, 'JSSC, n.d., signed T. Macafee on behalf of all CSEU unions, 'A Reply to the Company', ORG/GARDNER, WCML; Daily Mirror, 5 November 1980. 
sheets and posters were printed. ${ }^{119}$ The strikers framed the dispute in a way that highlighted their centrality to the firm. The convener was quoted: 'We believe it is our factory anyway, and we have elected to become custodians of it ... We will hand it back at the end in the same condition as we have taken it over' ${ }^{120}$ Another steward said: 'We've had enough of these Hawker Siddeley bastards shitting on us. It's our factory now. We're in control. We decide what happens. ${ }^{121}$ The strike's political significance and self-organized nature was also highlighted: 'Our national people never get out of their pram. They worry me to death because I don't know what they're up to ... [O]ur dispute's like a beacon, shining out of the gloom.' ${ }^{122}$

Despite such sentiments, strikers who spoke to the media emphasized the need for negotiations as soon as possible, with only the withdrawal of the ninety-day notices of redundancy as a precondition. ${ }^{123}$ The pressure placed on strikers and their families was evident: a letter to the convener from a striker's wife questioned the union's authority and tactics, adding that the company's secret ballot should have been respected: 'are you frightened of losing your fight for this action[?] ... [T] he strain of such action is on the wife and children ... I have been married ten years and have had enough of strikes etc. to last me a lifetime. ${ }^{124}$

Gardner delegations travelled extensively to raise money for the strike, visiting unions, workplaces, political groups, and demonstrations across the country. Engineering workforces across Manchester and in Sheffield voted to raise a levy to support them, although the strike finished before these were enacted. ${ }^{125}$ Visits to Gardner by activists from elsewhere included steelworkers who gave advice based on experiences of the 1980 steel strike; a delegation from Govan shipyards, including Jimmy Reid and Sam Gilmour, visited in solidarity and to pass on collections from their respective workplaces. ${ }^{126}$ Gardner workers had met Reid and others during Right to Work demonstrations in Scotland prior to the strike. ${ }^{127}$ Delegations were in general warmly welcomed but at one Birmingham factory, stewards told the delegation that managers had refused it access, having been warned

119 Bamford, 'The Gardners Dispute (1980)', ORG/GARDNER, WCML; Socialist Worker, 22 November 1980.

120 Guardian, 6 October 1980.

121 Socialist Worker, 11 October 1980.

122 Ibid., 18 October 1980.

123 JSSC, Convenor's Report, n.d., signed T. Macafee, ORG/GARDNER, WCML.

124 Letter, n.d., to T. Macafee from Mrs J.Hankinson (T. Macafee personal collection).

125 Letter, to All Branch Secretaries, 'L. Gardner and Sons Ltd.', from AUEW North Manchester District Committee, signed D. Daniels, 10 December 1980, ORG/ GARDNER, WCML.

126 Socialist Worker, 25 October 1980; Morning Star, 7 November 1980.

127 Interview, former Gardner shop steward, April 2015. 
of potential visits through a national EEF circular. ${ }^{128}$ Workers from a wide range of engineering, steel, shipbuilding, mining, and public-sector workplaces in Sheffield, Glasgow, Edinburgh, Huddersfield, Liverpool, Birmingham, Leeds, Bolton, Newcastle, south Wales, and London pledged solidarity and financial support. ${ }^{129}$ Union representatives from local firms, Adamson Containers and Chloride Batteries, provided support (including contact lists from solidarity work around their own recent disputes). ${ }^{130}$ Visits involved collections and attempts to strengthen confidence to resist redundancy and management attrition, and to 'keep in mind that we may have to call on you for Grunwick-style mass pickets if they try to throw us out with injunctions'. ${ }^{131}$

Workplaces visited by Gardner delegations were evidently under considerable pressure themselves, making their generosity even more special. One striker commented: 'I didn't think that support would be so good, especially as only one of the firms that I visited was not on short- time working, and they were making parts for nuclear bombs.' A Gardner delegate, together with Rotherham steelworkers who had made international links during their national strike earlier that year, visited a German steelworkers' conference, which paid his fares. ${ }^{132} \mathrm{~A}$ total of $£ 75,000$ was collected during the strike: of this, around $£ 41,000$ was paid as strike benefit; $£ 13,000$ was held in a joint CSEU strike fund to support other workers; and the remainder was spent on administration, stationery, food and delegation expenses. ${ }^{133}$ The delegation work was not without controversy; at a meeting of civil service union activists in London, the Gardner convener was 'attacked by 4 people for calling Thatcher a "bitch" ... [T] he crucial importance of the Gardners struggle was overshadowed for some by a burning zeal for "purism" at all costs. ${ }^{134}$

128 Socialist Worker, 1 November 1980.

129 Socialist Worker, 1, 15 November 1980.

130 Former senior steward, 'L. Gardner and Sons 1980-82', GB WCML.

131 Harman, 'Organising for Occupation', Soc. Rev. The 1976-78 strike at Grunwick, west London, where 137 workers were dismissed for taking part, involved mass pickets drawn from across the country and wider labour movement seeking to prevent replacement workers from crossing picket lines:

J. McGowan "'Dispute", "Battle", "Siege", "Farce"? - Grunwick 30 Years On',

Contemporary British History 22:3 (2008), pp. 383-406.

132 'Delegation News: Newssheet of the Delegation, Transport and Fundraising Committee', n.d., ORG/GARDNER, WCML.

133 Bamford, 'The Gardners Dispute (1980)', ORG/GARDNER, WCML; Former senior steward, 'L. Gardner and Sons 1980-82', GB WCML.

134 Socialist Worker, 29 November 1980. Further controversy involved some private criticism from John Tocher over the involvement of the SWP and the SWP-led Right to Work campaign: 'Criticism of the way we are spreading the dispute without the sanction of the officials and similar accusations 
The Advisory, Conciliation and Arbitration Service (ACAS) offered to conciliate at the end of October. ${ }^{135}$ But by then the occupation was causing the company considerable problems and an informal meeting was held on 8 November between regional AUEW officials and the chairman of Hawker Siddeley diesel division. Work-sharing was discussed for the first time; a draft proposal was taken to the EEF on 10 November, with redundancy notices temporarily withdrawn. ${ }^{136}$ In initial negotiations, the company proposed a return to work with work-sharing and a temporary withdrawal of redundancy notices until February 1981; but these were to be accompanied by new flexibilities and changes to trade demarcations that the stewards rejected. The company also threatened another ballot if the strike was not settled on its terms. Negotiations continued with the role of stewards, another issue raised by management.

All-night talks took place on 19 and 20 November. The fact that union conveners on the docks had agreed to embargo Hawker Siddeley products, if the dispute continued, helped to force a settlement. The convener and chairman were brought in to approve the final proposals. ${ }^{137}$ The agreement involved 275 redundancies by February 1981 rather than 21 December 1980, with additional short-time working if this target was not met; there would be a nine-month consultation over the redundancies, none of which would be compulsory. A JSSC meeting on 24 November voted unanimously to accept, as did a mass meeting on 25 November; production resumed on 26 November. ${ }^{138}$

A Gardner delegation featured prominently at a Labour Party-organized demonstration against unemployment the next weekend. Management congratulated the chairman and convener for their 'good order' during the strike, and 2,500 letters of thanks were sent by the strikers to the many labour movement organizations that had supported them. ${ }^{139}$ This letter hailed a victory

not only for the Gardner (Hawker Siddeley) workers, but for the whole of the Trade Union and Labour Movement against the might of the Multi-National

of Trotskyist infiltration are expected and we have experienced them all through the dispute, particularly from CP hardliners, but we did not expect such criticism from Tocher': Former senior steward, 'L. Gardner and Sons 1980-82', GB WCML.

135 AUEW Manchester North District committee, 28 October 1980, TU/ ENG, WCML.

136 Ibid.

137 Former senior steward, 'L. Gardner and Sons 1980-82', GB WCML.

138 AUEW Manchester North District committee, 25 November 1980, TU/ ENG, WCML; Morning Star, 24, 26 November 1980.

139 Former senior steward, 'L. Gardner and Sons 1980-82', GB WCML. 
... In these very difficult times, with the most reactionary Tory Government in the history of modern politics attempting to smash the unions, we are naturally proud of our achievement, and hope the hardship we have endured during the $71 / 2$ weeks of occupation will be compensated by encouraging other workers to fight for their jobs. ${ }^{140}$

The agreement, involving work-sharing, was deemed 'revolutionary' by key shop stewards, although a wider recovery maintaining employment levels was ultimately unfeasible as orders did not recover. ${ }^{141}$

Problems soon emerged: delays in implementing the $5 \%$ pay rise led to a oneday stoppage on 17 December, and further conflicts arose over the introduction of a new payment system in February 1981, which removed the right of workers to declare day-work, effectively ending Gardner workers' rights under the Manchester Piecework Agreement. In May, 350 workers were still on short-time, and reduced staffing meant that Gardner was unable to meet orders due to parts shortages. ${ }^{142}$ 'After last year's bloody nose', Hawker Siddeley 'appear to be clearing the decks for another go' was one view; and, although the 1980 action demonstrated that redundancies could be opposed, the workforce had been 'softened up' by months of short-time working. ${ }^{143}$ By July, the large majority were working two days per week, and 500 (410 manual and 90 staff) redundancies were announced in August 1981. An overtime ban started in September. The company responded, in a letter to employees, by accusing the works committee of being 'a malignant minority pursuing revolutionary objectives'. Total redundancies were reduced to 365 , with all but 40 accounted for by voluntary severance or internal transfers. $^{144}$

In January 1982, Macafee was challenged by Ray Robinson, the former convener, and was voted out as convener and as shop steward. This represented a move away from militant unionism at Gardner; pay offers - including 3\% in January 1982, well below inflation - were reluctantly recommended by stewards and accepted by over $80 \%$ of the workforce. In February, a dispute arose where a worker was suspended, and a section meeting in the milling department agreed to walk out in support if it went ahead. Twenty minutes into this dispute, Brightman, the deputy convener and section shop steward, was suspended for opposing the foreman's orders and ordered off the site pending an investigation. Within two hours $80 \%$

140 Letter, from T. Macafee, November 1980, 'To all trade union and labour movement organisations: CSEU dispute L. Gardner and Sons, Eccles, Manchester', ORG/GARDNER, WCML.

141 Interview, former Gardner shop steward, February 2015.

142 Former senior steward, 'L. Gardner and Sons 1980-82', GB WCML.

143 The Charter, October/November 1981.

144 Former senior steward, 'L. Gardner and Sons 1980-82', GB WCML. 
of the membership had downed tools, and Brightman was served with a dismissal notice for not leaving immediately; he was reinstated as a worker and steward after a stoppage of several days. ${ }^{145}$ In August 1982, a further 500 jobs were deemed at risk, and on 10 September a mass meeting voted 70-30 against stewards' recommendations to resist, conceding redundancies and changes to piecework. Brightman left Gardner in October. With key activists such as Macafee and Brightman no longer in the factory leadership, the unions on site were far weaker than only two years previously. ${ }^{146}$

Workforce acquiescence to these various changes marked a major shift in industrial relations at Gardner. Large numbers of experienced workers and union activists left, and the increasingly precarious nature of demand for Gardner engines meant that union organization was significantly weakened as the firm went into its final decline. Established practices based on 'mutuality' where working times and work organization would be agreed locally between unions and management were eroded ${ }^{147}$ with managerial control reasserted through regular redundancies.

New engines were introduced but were often more expensive and powerful than needed by many operators, and less reliable than earlier models. Key firms within the Leyland group, including Guy, Daimler and Bristol, which often fitted Gardner engines, closed down, and other buyers such as ERF, Foden, and Seddon Atkinson were also in decline. Hawker Siddeley sold off many component firms and divisions, including (in 1986) Gardner, to the Massey Ferguson-owned Perkins Engines (whose 385,000 engines per year dwarfed Gardner's output). ERF and Seddon Atkinson delisted Gardner engines as an option on their vehicles by 1990 , and competition increased from far larger, diversified and internationalized firms. Perkins eventually sold Gardner, and automotive -engine production ceased in 1994. Spare parts were produced until around 2000.

Fundamental to Gardner's decline was its nature as a small, specialized producer within increasingly competitive and internationalized product markets, and the chaotic implementation of outsourcing and new technology in the 1980s. ${ }^{148}$ Industrial relations had been conflictual and led to some long disputes, but ultimately did not have a decisive bearing on Gardner's prospects compared to the wider structural changes and recession that marked the final years of the firm's existence.

145 Ibid.; AUEW Manchester North District committee, 23 February 1982, TU/ ENG, WCML.

146 Former senior steward, 'L. Gardner and Sons 1980-82', GB WCML.

147 Stewart et al., We Sell Our Time No More, p. 132.

148 Edge, L. Gardner \& Sons Limited, pp. 191-4; Halton, 'L. Gardner and Sons', p. 135. 


\section{Conclusion: mobilization and employer retribution in the early Thatcher period}

While the 1980 Gardner strike was relatively small, it remains significant for a number of reasons. Most notably, it represented a partial victory in a period when strikes were declining and increasingly difficult to organize. The organization displayed by the Gardner workforce was remarkable and, as shown in contemporaneous accounts, it represented some hope that workers could mobilize against mass redundancy. The nature of the firm, with its closed shop, a single site, and residual strength deriving from engineering craft traditions, made this more achievable than in many other workplaces. Strong union organization, management's mistrust of the workforce, and ongoing conflict over pieceworking meant that, as in another celebrated factory, ' $[\mathrm{t}]$ he union played a central role in the work experiences of its members, while these institutional factors and the continual reaffirmation of union principles ... kept alive notions of unity and the collective interest'. ${ }^{149}$ The weakening of union organization in engineering during the $1980 \mathrm{~s}$ meant that employers could increasingly determine employment conditions at the workplace; multi-employer bargaining ended in 1989 when the EEF eventually withdrew, leaving many less well-organized factories exposed. ${ }^{150}$

Comparison with the 1981 strike and occupation at Laurence Scott (in nearby Openshaw, Manchester), where the workforce was ultimately defeated, is instructive. That dispute was over closure, which was much harder to resist. More forceful use of police (with some military support), withdrawal of support by the national AUEW, tensions between workforces on different sites (those staying open were 'blacked' by the strikers), and the firm's willingness to seek injunctions to remove the occupiers, also contributed to defeat ${ }^{151}$. But portraying the Gardner strike as a victory was problematic: 275 jobs were lost in 1980 alone and it was argued that this needed to be acknowledged in order to resist the counter-mobilization that followed. ${ }^{152}$ As outlined above, the Gardner occupation was not a spontaneous response to the economic and political context, but had its roots in the fluctuating struggle from the early 1960s to build up shop-floor unionism and develop a factory leadership prepared to challenge the management.

The 1980 dispute was driven by the workforce and stewards, with support from local left-wing union officials; national support, often not forthcoming from the AUEW, was secured through intensive lobbying of the union's headquarters. Key figures in the local union leadership were politically active and this contributed significantly to their capacity to gain support. But the

149 Batstone et al., The Social Organization of Strikes, p. 222.

150 Joyce, 'The Engineering Employers' Federation', HSIR, p. 164.

151 Love, Conflicts over Closure.

152 McIlroy, Strike!, pp. 205-6. 
1980 strike was mainly driven by the factory union organization, whereas full-time officials played a greater role in the 1973 dispute. In 1973, the strike was undermined by more quiescent stewards, who were subsequently removed, as well as by the lack of a closed shop. The combative nature of management aided efforts to strengthen union organization in the firm, with white-collar staff also joining unions. The 1980 occupiers had learned from the 1973 experience, showing far greater unity and more assertive leadership. While the factory management's intransigence contributed towards these dynamics, the Hawker Siddeley takeover was also significant: this multinational parent company represented a common enemy beyond Gardner management and any residual loyalty it might command. The context of the first major post-war recession and the unpopular Thatcher government also galvanized attitudes during the dispute.

The dynamism of the 1980 Gardner occupation also contrasts markedly with the experience of the 1972 wave of sit-ins in Greater Manchester, where only a few managements were locked out. In 1972 the broad left local union officials did not utilize shop-floor organization fully, and there was a lack of co-ordination between plants which allowed employers to restrict settle-ments. ${ }^{153}$ In 1980 the emphasis on rank-and-file participation and fundraising independent of AUEW strike benefit, and the rapid move to a full occupation of the plant constituted a reaction to the weakness of the 1972 tactics. Key figures in the workplace union leadership in 1980 included members of the CP, Labour Party and SWP, and there was an acceptance of the SWP's role in building wider solidarity, creating links and raising money that surpassed what could be organized by broad left and CP officials.

The analysis of the 1980 strike, given here, contrasts with arguments that 'strikes in situations of mass workforce reductions are not triggered by the threat of job loss per se but instead by the threat such situations may pose to the union organization', ${ }^{154}$ although the forceful responses to victimization of shop stewards and the erosion of 'mutuality' demonstrate the importance of defending union structures that underpinned the wider aims of the strike. Networks utilized by Gardner strikers drew on those established in earlier disputes including the engineering sit-ins of 1972, the Roberts-Arundel strike of the late 1960s and other, smaller disputes where solidarity campaigning was widespread. Full-time officials such as Tocher made important interventions around the 1972 and 1973 Gardner strikes, which influenced the organization of the 1980 occupation; but the dispute was driven from below, including pressure from Gardner activists on the national union leadership, which would have been unwilling and incapable of mounting such a strike.

153 Darlington and Lyddon, Glorious Summer, pp. 127-34.

154 Golden, Heroic Defeats, p. 138. 
As the 1980s progressed, the occupation tactic was used less frequently. State and employer responses became more forceful, as in 1984 at Cammell Laird where occupiers faced injunctions, arrest and imprisonment. ${ }^{155}$ Occupations against redundancy and closure in the 1970s could potentially draw on state intervention in the form of full or part-nationalization to preserve employment, an approach forcefully rejected by the Thatcher governments and constraining the potential outcomes of such action. ${ }^{156}$ Interest rate rises after Thatcher's election meant the cost of loans from Hawker Siddeley wiped out Gardner's profits and contributed to the decision to impose redundancies. The focus on short- term results within the cash-rich, but precarious, parent company, Hawker Siddeley, following nationalizations and the loss of military contracts during the 1974-79 Labour government, further underpinned Gardner's 1980 crisis. The wider economic climate, the example given by managers such as Edwardes at British Leyland and the government's rhetorical attacks on trade-unionism, facilitated Gardner's counter-mobilization against union organization. The removal of key leaders and ongoing job losses, while implemented chaotically at times, represented a powerful form of retribution, highlighted by Kelly as a challenge to gains achieved through militant trade-unionism but often underrepresented in other accounts using mobilization theory. ${ }^{157}$

High unemployment and collapsing demand was the main 'disciplining' factor limiting workers' opposition in the early 1980s. ${ }^{158}$ In the years that followed, more direct attacks by employers on workplace union leaders and established procedures, and the developing legal and political campaign against trade unions, militated against strikes and occupations over redundancies and closures - though the 1984-85 miners' strike was an exceptional act of resistance. The erosion of the concessions won by the 1980 Gardner strike and occupation, including further redundancies in 1981 and 1982, demonstrate the fragility of gains achieved through trade-unionism. They also demonstrate the difficulty of maintaining strong workplace organization in the face of recession, deindustrialization and countermobilization by employers and the state in Britain in the 1980s.

155 Mustchin, ‘From Workplace Occupation', HSIR.

156 Tuckman, 'Workers' Control'.

157 Kelly, Rethinking Industrial Relations.

158 Davies and Freedland, Labour Legislation, pp. 80-4. 